\title{
THE ANALYSIS OF AGRICULTURAL PRODUCT IN PINEAPPLE COMMODITIES IN NGANCAR DISTRICT, KEDIRI REGENCY, EAST JAVA PROVINCE
}

\author{
Risdiana Himmati* \\ Department of Economics \\ Faculty of Economics and Business, University of Sebelas Maret
}

\begin{abstract}
The purpose of this research is to analyze the factors affecting the production of pineapple in Ngancar District, Kediri Regency, East Java Province. The research took place in Ngancar District, Kediri Regency, East Java Province, using the secondary data derived from Central Bureau of Statistics (Kediri Regency) and Agricultural Extension Agency (Ngancar District) and the primary data consisted of farming production data, land area, amount of seeds, and amount of fertilizer used, pesticide used and workforce. The analysis technique used in this research was Cobb-Douglas production function. The completion of Cobb-Douglas production functions used Ordinary Least Square (OLS) method. The sampling technique used in this research was a simple random sampling method. The results demonstrate that the pineapple total production in Ngancar District is affected by land area, amount of seeds, molasses, and the urea. The research concludes that pineapple production in Ngancar District is affected by all the factors of production, except the usage of pesticide and workforce.
\end{abstract}

Keywords: Pineapple, Cobb-Douglas, OLS, Simple Random Sampling

JEL Classification: Q02, Q13

\section{INTRODUCTION}

Pineapple is fruit plant originating from areas in Brazil, but widely grown and developed in Indonesia. It is widely cultivated in Indonesia, either as plantation plants, planted on yard, or planted in places receiving plenty of sunshine at 1-1300Mdpl. Pineapple does not have the specific fruiting season throughout the year, neither in 12 months nor 18 months period, with an average altitude approx. 50-150 cm (Sugeng, 2010).

Indonesia is one of the countries with a high level of pineapple exports. Commencing in 2010, Ministry of Agriculture of Indonesia recorded around 59,009 tons of pineapple had

*Corresponding e-mail: risdiaana@gmail.com 
been exported to many countries. Until 2014, it was recorded that 192,315 tons of pineapple had been exported.

Table 1. Development of Pineapple Export in Indonesia in 2010-2014

\begin{tabular}{|c|c|c|}
\hline Year & $\begin{array}{c}\text { Export Volume } \\
\text { (Ton) }\end{array}$ & Growth (\%) \\
\hline 2010 & 59,009 & -67.09 \\
2011 & 189,223 & 220.67 \\
2012 & 183,072 & -3.25 \\
2013 & 174,096 & -4.90 \\
2014 & 192,315 & 10.46 \\
\hline
\end{tabular}

Source: Pineapple Outlook, Ministry of Agriculture, 2014

Ngancar District is located in Kediri Regency, East Java Province. It has an area of 2,376 hectares of land, planted with pineapple with farmers managing it reach to 5,884 in total (BPP of Ngancar District, 2016). Kediri's regency government keeps developing pineapples into a leading commodity of Ngancar District, as geographically, it is located in the base of Mount Kelud at an altitude between 225 and 380 Meters above sea level (BPS of Kediri Regency, 2015).

The type of land in Ngancar District is alluvial soil with the characteristics of consisted of sandy loam with sand content approximately 30\%, in a tropical climate condition with the air temperature ranges at intervals of 25-30 degree Celcius. Ngancar District becomes a suitable place for pineapple cultivation and the development as a whole, so it is reasonable when Kediri Regency makes pineapple as a major commodity in Ngancar District in addition to cow's milk and vegetables.

Pineapple is one of horticulture commodity that having a high prospects and potential to be developed over time; hence regency government of Kediri keeps encouraging farmers in Ngancar District to cultivate pineapple in order to meet the demand. With geographic location at the base of Mount Kelud, pineapple will thrive with a sufficient light intensity and air. Thereby, with the relevant government encouragement, there will be many farmers cultivating pineapple. It underlies Ngancar District as one of tourist attraction of Mount Kelud.

Currently, pineapple is a leading product that keeps being developed. For Kediri Regency's government, pineapple is not just a tropical fruit with sweet and sour taste, but it 
also has a high development in terms of economy. One type of pineapple that commonly planted in Ngancar District is local pineapple that can be sold up to IDR 1000,- per seed. Therefore, it is also a good source of economic benefits for farmers and local officials in order to increase locally-generated revenue from farming.

There are various cropping patterns of Ngancar District, ranging from vegetables to fruit. Below is the cropping pattern of Ngancar District's community in 2016.

Table 2. Planting Pattern of Agricultural Land Ngancar District, 2016

\begin{tabular}{|c|c|c|c|}
\hline No & Planting pattern & $\begin{array}{r}\text { Area } \\
\text { (Ha) }\end{array}$ & $\begin{array}{l}\text { Number of } \\
\text { Farmers, } \\
\text { Administrators }\end{array}$ \\
\hline \multirow[t]{2}{*}{1} & Wetland & & \\
\hline & Paddy-paddy-paddy & 91.8 & 296 \\
\hline \multirow[t]{6}{*}{2} & Paddy-paddy-dry season crops & 96 & 312 \\
\hline & $\begin{array}{l}\text { Paddy=vegetables/Horticulture } \\
\text { dry season crops }\end{array}$ & 226 & 382 \\
\hline & $\begin{array}{l}\text { paddy-horticulture- } \\
\text { horticulture }\end{array}$ & 224 & 368 \\
\hline & $\begin{array}{l}\text { horticulture -paddy- } \\
\text { horticulture }\end{array}$ & 96 & 214 \\
\hline & Sugarcane & 148 & 419 \\
\hline & Total & 790 & 1991 \\
\hline \multirow[t]{11}{*}{3} & Dry land & & \\
\hline & Pineapple & 2,376 & 5,884 \\
\hline & Papaya & 113 & 509 \\
\hline & Longan & 59.72 & 2,761 \\
\hline & Strawberry & 2 & 5 \\
\hline & Sugarcane & 120 & 1,210 \\
\hline & Clover and coffee & 105 & 215 \\
\hline & Horticulture/ vegetables & 69 & 207 \\
\hline & Coffee + clover + banana & 70 & 399 \\
\hline & clover + papaya + pineapple & 119 & 340 \\
\hline & Total & 2,108 & 9,525 \\
\hline
\end{tabular}

Source: BPP Ngancar District, 2016

Table 2 indicates that the cropping pattern of Ngancar District, consisting of various staffs and staples, as well as fruits. However, it appears that in an area of 2,376 Ha, the number of farmers managing pineapple is 5,884. It can be said that pineapple is a fruit crops that dominate the cropping pattern. 
Ngancar District is also a tourist destination due to the existence of Mount Kelud; one of volcanoes that remains active until today, and has recorded for last erupted on February 14, 2014 (BPP District Ngancar, 2016). Up to 2014, the total of pineapple production in Ngancar District is 1,328,399 Kw of the total land in Ngancar District (Ngancar District in Figures, 2015), making Ngancar District as one of many areas in Indonesia as a pineapple producer with various types.

\section{MATERIALS AND METHODS}

The research used primary and secondary data. Primary data were obtained through interview techniques to the farmers using question method guidance, including farming production, land area, amount of seeds, and amount of fertilizer used, pesticide used and the labor. Secondary data were obtained from Central Bureau of Statistics (Kediri) and Agricultural Extension Agency (Ngancar District), including data on the number of pineapple farmers. The data analysis technique used is production function analysis of Cobb-Douglas in order to determine the influences of production factors to pineapple production in Ngancar District, Kediri Regency. The production function used in this research is Cobb-Douglas production function. Cobb-Douglas's is used to determine the extent to which the influence of each independent variable to production as dependent variable.

The sampling technique in this research is a simple random sampling method. The sampling technique deliberately used simple random sampling because the pineapple farmers were spread throughout the district consisted of 6 and each village had large and spacious pineapple farming. Therefore, suitable sampling method was by using simple random sampling method while using basic data as guidance.

The sampling was based on data on Ngancar District's farmer groups. The respondents would be interviewed. The amount of farmer groups' samples can be seen in Table 2 below. 
Table 2. The Amount of Pineapple Farming Samples according to Farmers Group Association Ngancar District, 2016

\begin{tabular}{|c|c|c|c|}
\hline No & Farmers Group & Village & $\begin{array}{c}\text { Total } \\
\text { samples }\end{array}$ \\
\hline 1 & Gayuh Mulyo & Sugihwaras & 28 \\
2 & Sugih makmur & Sugihwaras & 37 \\
3 & Mulyo tani & Sugihwaras & 43 \\
4 & KWT Karya usaha & Manggis & 35 \\
5 & KWT Lestari & Babadan & 49 \\
6 & KWT Lestari & Jagul & 25 \\
\cline { 1 - 2 } & \multicolumn{2}{|c|}{ Total } & 220 \\
\hline
\end{tabular}

Source: Agricultural Extension Agency, Ngancar District, 2016 Description: KWT is Women Farmers Group

Based on the existing farmer groups' data, each farmer group comprised of 5 out of 6 farmer groups; and 10 farmers will be added from non-farmer groups.

In this research, the dependent variable is Pineapple Total Production (TP), and the independent variable or related variable are Land Area (LH), seeds (BNH), fertilizers (KDP), pesticide (PES), and Workforce (TK). For fertilizer variable (KDP) is split into two parts; hence becoming Molasses (TTS) and Urea (UA).

Based on the theoretical model of Cobb-Douglas equation function, the following is formulated (Soekartawi, 2005);

$$
Q=f(K, L)=A \cdot K^{a} L^{a}
$$

Description:

$$
\begin{array}{ll}
\mathrm{Q} & =\text { Production quantity } \\
\mathrm{K} & =\text { Capital } \\
\mathrm{L} & =\text { Workforce } \\
\mathrm{A}, \mathrm{a}, \mathrm{b} & =\text { Predicted amount }
\end{array}
$$

To make it easier, the equation is changed in the form of multiple linear equations by means of making logarithm of the equation into equation as follows:

$$
\log Y=\log \alpha+\beta 1 \log K+\beta 2 \log L
$$

The interpretation of the parameters of the above equation is as follows:

a. $\alpha$ is the level of efficiency in overall production process. The greater $\alpha$, the more efficient the production organization. 
b. Parameter $\beta$ measures the elasticity of production for each factor of production.

c. The amount of $\beta$ indicates the level of scale returns.

d. Parameter $\beta$ can be used to measure the intensity of production factors usage.

Cobb-Douglas production function has the characteristics of combination of input is technically efficient. The input is fixed and is subjected to Law of Diminishing Return (Arsyad, 1991). Cobb-Douglas production function should be put into logarithm, and the functions should be transformed into linear function in the usage in production analysis completion.

Therefore, when applied to the function of pineapple farming production, CobbDouglas production function completion with Ordinary Least Square (OLS) method using Eviews 9 program with equation model is obtained as follows:

$$
\begin{aligned}
\log \mathrm{TP}= & \log \alpha+\alpha \beta_{1} \log \mathrm{LH}+\beta_{2} \log \mathrm{BNH}+\beta_{3} \log \mathrm{TTS} \\
& +\beta_{4} \log \mathrm{TTS}+\beta_{5} \log \mathrm{UA}+\beta_{6} \operatorname{LogTK}+\mu
\end{aligned}
$$

Description

$\begin{array}{ll}\text { Log TP } & \text { : Total production Log } \\ \text { LogLH } & \text { : Land area Log } \\ \text { LogBNH } & \text { : Seed Log } \\ \text { LogTTS } & : \text { molasses Log } \\ \text { LogUA } & \text { : Urea Log } \\ \text { LogTK } & \text { : Workforce Log }\end{array}$

\section{RESULTS AND DISCUSSIONS}

This research was undertaken using primary and secondary data. The primary data were obtained from interviews with the assistance of questionnaires method, and the secondary data were obtained from BPS of Kediri Regency, and BPP of Ngancar District. The calculation result of production function of Cobb-Douglas on pineapple faming production in 2016 can be seen in Table 1. 


\begin{tabular}{|c|c|c|c|c|c|}
\hline \multicolumn{6}{|c|}{ Ngancar District Kediri Regency } \\
\hline No & $\begin{array}{c}\text { Name of } \\
\text { variables }\end{array}$ & $\begin{array}{l}\text { Variable } \\
\text { notation }\end{array}$ & $\begin{array}{l}\text { Coefficient } \\
\text { regression }\end{array}$ & t stat & Prob. \\
\hline 1 & Constant & Constant & 5.582 & 24.419 & 0.000 \\
\hline 2 & Land area & Log LH & 0.473 & 12.794 & 0.000 \\
\hline 3 & Seed & Log BNH & 0.494 & 40.999 & 0.000 \\
\hline 4 & Molasses & Log TTS & 0.073 & 2.053 & 0.050 \\
\hline 5 & Urea & Log UA & -0.013 & -3.179 & 0.003 \\
\hline 6 & Pesticide & Log PES & -0.001 & -0.456 & 0.651 \\
\hline 7 & Workforce & Log TK & -0.028 & -1.632 & 0.114 \\
\hline & $\mathrm{R}^{2}$ & & 96 & F-stat & $1,426.847$ \\
\hline & Adj $R^{2}$ & & 96 & Prob F & 0.000 \\
\hline Dur & in-Watson & & & & \\
\hline
\end{tabular}

Source: Primary data regression analysis using Eviews 9, 2016

Based on the regression result of table 1, the following equation is drafted as follows:

$$
\begin{aligned}
\operatorname{LogTP}= & 5,582+0,473 \operatorname{LogLH}+0,494 \operatorname{LogBNH}+0,073 \operatorname{LogTTS} \\
& -0.013 \operatorname{LogUA}-0.001 \text { LogPES }-0.028 \operatorname{LogTK}
\end{aligned}
$$

Based on the equation obtained from table 1, it is known that out of six variables affecting the production of pineapple at Ngancar District, the only two variables that do not affect are pesticide with a probability value of 0.651 or greater when compared with $\alpha=$ $5 \%$. Similarly, the workforce used on pineapple farming doesn't really affect the pineapple production level at Ngancar District with a probability value of 0.114; greater when compared to $\alpha=5 \%$.

Four variables affecting the pineapple total production is the land area, which is basically, the larger land used to grow pineapple, the greater the pineapple production because the land area maximized in pineapple planting will result in greater production. Next is seed. The more seed planted in the more extensive land will greatly affect the pineapple production and minimize production failures due to the amount of seeds planted. Fertilizer is also a factor affecting the pineapple total production in Ngancar District. There are two types of fertilizer used by farmers: molasses fertilizer classified as organic fertilizers and environmentally friendly as a form of waste utilization; and inorganic fertilizers, namely urea that also affects the pineapple's fertility to progressively increase pineapple production. 
Pesticide and workforce used in pineapple production at Ngancar District have no effect because farmers do not use large amount of pesticide. For workforce, the pineapple farmers rely more on family members; hence the number of workforce has no effect. As according to farmers, family members will not be much concerned with working hours and wages, thus regardless the number of workers, pineapple production will remain the same.

Therefore, the interpretation made is as follows: production factor of land area has a coefficient value of 0.437 with a degree of probability smaller than $\alpha=5 \%$, which means any increase in land area usage of $1 \%$ will increase pineapple production by $0.473 \%$. Furthermore, pineapple seed has a coefficient of 0.494 with a probability smaller than $\alpha=$ $5 \%$. Thereby, any increase in the use of seeds of $1 \%$ will affect the total production by $0.494 \%$ or pineapple production will increase with additional $1 \%$ of each seed used.

Also, molasses production factor that has a coefficient of 0.073 with a probability smaller than $\alpha=5 \%$, which means each $1 \%$ increase in molasses usage, then it will increase the total production of pineapple at $0.073 \%$ and for production factor, the use of urea has a value coefficient of -0.013 with a negative sign, but having the probability smaller than $\alpha=$ $5 \%$, which means any reduction in the urea usage by $1 \%$ will affect the level of pineapple production by $0.013 \%$.

In the regression model used in the research, classical assumption test that will still be used by the data normality test sequence is first classical assumption test, data normality test are used to find out whether the model in regression, both dependent variable and independent variables have a normal distribution or nearly normal. Data normality test used is to identify the Jarque-Bera value if Jarque-Bera value is greater than Chi-Square value at $\alpha 5 \%$, thus the normality assumption cannot be met (Ghozali, 2013). 
Table 4. Normality test

\begin{tabular}{|c|c|c|c|}
\hline \multicolumn{2}{|c|}{ Prior to Trimming } & \multicolumn{2}{|c|}{ Following Trimming } \\
\hline \multicolumn{2}{|c|}{$\begin{array}{l}\text { Series: Residuals } \\
\text { Sample } 140 \\
\text { Observations } 40\end{array}$} & \multicolumn{2}{|c|}{$\begin{array}{l}\text { Series: Residuals } \\
\text { Sample } 133 \\
\text { Observations } 33\end{array}$} \\
\hline Mean & $-9.91 \mathrm{e}-16$ & Mean & $-1.37 e-15$ \\
\hline Median & 0.014281 & Median & 0.002400 \\
\hline Maximum & 0.510816 & Maximum & 0.164866 \\
\hline Min imum & -0.225297 & Minimum & -0.145238 \\
\hline Std. Dev. & 0.136033 & Std. Dev. & 0.065054 \\
\hline Skewness & 1.220084 & Skewness & 0.492505 \\
\hline Kurtosis & 6.514327 & Kurtosis & 3.577519 \\
\hline Jarque-Bers & 30.50819 & Jarque-Ber & 1.792689 \\
\hline Probability & 0.000000 & Probability & 0.408059 \\
\hline
\end{tabular}

Source: Primary data of regression analysis using Eviews 9, 2016

In table 4 normality test result on regression data prior to trimming shows JarqueBera value is greater than Chi-Square value at $\alpha 5 \%$, thus the normality assumption is not met; therefore trimming is done or removing data becoming outliers (Ghozali, 2006). Handling the data that have outliers can be undertaken using several ways. This research used trimming method, i.e. removing the data that become outliers, so as to get Jarque-Bera value smaller than Chi-Square value at $\alpha 5 \%$ is shown in table 4 . Normality testing after trimming method will be fulfilled or regression data will be distributed normally.

Further classical assumption testing has multicollinearity test. This test is used to test a model, whether a strong relationship occurs between independent and correlated variables model. If a model has a VIF value $>10$ then the model does not have regression qualification; otherwise if VIF $<10$, thus the model is qualified. In the regression model, VIF independent values are $6.539,2.447,5.665,1.731$ 1.071, 1.238, respectively. Thereby, the model is free from multicollinearity problems.

Heteroscedasticity testing is used to identify whether the regression model has the same variant or not from one treatment to another treatment (Ghozali, 2013). The Heteroscedasticity test results using white method shows Obs*R Squared value is equal to 5.2819 with a probability of 0.5082 or greater than $\alpha=5 \%$, so there is no Heteroscedasticity problem in the model.

Autocorrelation test is used to test whether the regression model has a correlation between errors in observation members or others in different time (Widarjono, 2013). D- 
$\mathrm{W}$ value is located between $\mathrm{du}<\mathrm{d}<4-\mathrm{du}$; thereby independent variables used in the model are free from autocorrelation.

Statistical test used in the regression model is comprised of the F test, coefficient of determination (R2). F test is performed to determine whether the production factors used have significant concurrent effects to the production result. From table 3 on the discussion, it is known that F count is 1426.847 with a probability value of 0.000 , which means six independent variables jointly influence variable of pineapple total production.

The coefficient of determination in the regression model is 0.996 , equal to $99.6 \%$, which means that the pineapple farming is affected by the production factors incorporated into the model, while the remaining, at $0.4 \%$ is affected by other factors not included in the model.

\section{CONCLUSIONS}

Based on the results, it is concluded that all production factor that has significant effect is the land area. The land area greatly affects pineapple production level and pineapple production outcome. The larger the area owned, the greater of pineapple harvested. For seed production factor, it also determines pineapple production outcome. It is also demonstrated by regression analysis; that seed has effect on production. Furthermore, molasses organic fertilizer and urea significantly affect the pineapple production outcome. The wide usage of molasses as fertilizer is because organic fertilizer serves as one factor helping the soil enrichment.

\section{REFERENCES}

Widarjono, Agus. (2013). Ekonometrika: Pengantar dan aplikasinya, Ekonosia, Jakarta Arsyad, Lincolin., (1991), Ikhtisar Teori dan Soal Jawab Ekonomi Mikro, BPFE, Yogyakarta BPS. (2012). Kecamatan Ngancar Dalam Angka. Badan Pusat Statisika : Kabupaten Kediri BPS. (2015). Kabupaten Kediri Dalam Angka. Badan Pusat Statisika : Kabupaten Kediri BPS. (2015). Kecamatan Ngancar Dalam Angka. Badan Pusat Statisika : Kabupaten Kediri Ghozali, Imam, (2006). Aplikai Analisis Multivarite dengan SPSS, Cetakan 
Ghozali, Imam, (2013). Aplikasi Analisis Multivariat dengan Program IBM SPSS 21. Edisi 7, Penerbit Universitas Diponegoro, Semarang.

Soekartawi, (2005). Teori Ekonomi Produksi : Dengan Pokok Bahasan Analisis Fungsi CobbDouglas. Jakarta: Rajawali Press.

Sugeng. (2010). Tanaman Apotik Hidup. Semarang: Aneka Ilmu. 